\title{
Znaczenie pomiaru cząstkowej rezerwy przepływu wieńcowego (FFR) a iFR - czy potrzebujemy nowej techniki do oceny istotności zwężenia naczyń wieńcowych?
}

\author{
Assessment of fractional flow reserve (FFR) vs iFR - do we need \\ new technology for the diagnosis of coronary stenosis?
}

\author{
Bartosz Górny, Wojciech Balak, Władysław Sinkiewicz
}

II Katedra Kardiologii Uniwersytetu Mikołaja Kopernika w Toruniu, Collegium Medicum w Bydgoszczy

\section{Streszczenie}

Pomiar cząstkowej rezerwy przepływu wieńcowego (FFR) jest precyzyjną oceną istotności zwężenia w naczyniach wieńcowych, którą można łatwo i szybko wykonać w trakcie koronarografii. Pomiar ten od lat stanowi podstawowe narzędzie w kardiologii interwencyjnej przy podejmowaniu decyzji dotyczącej stentowania zmienionego naczynia wieńcowego. Z kolei rozkurczowa ocena gradientu ciśnienia (iFR) jest stosunkowo nowym, pomocniczym narzędziem w ocenie istotności zwężenia naczynia wieńcowego, mierzącym gradient przez zwężenie w trakcie rozkurczu. Podczas konferencji American College of Cardiology w 2017 roku podczas Scientific Sessions w Waszyngtonie przedstawiono wyniki 2 dużych, randomizowanych badań, iFR-SWEDEHEART i DEFINE-FLAIR, służących porównaniu bezpośrednio iFR i FFR u blisko 4500 pacjentów. Opublikowane wyniki wskazują, że iFR jest nie gorszym narzędziem diagnostycznym niż FFR, z porównywalnym głównym punktem końcowym w ocenie rocznej. Pozostaje czekać na kolejne wyniki badań, w których zostaną porównane FFR i iFR oraz dalszą, odległą obserwację chorych poddanych analizie istotności zwężeń w naczyniach wieńcowych.

Słowa kluczowe: FFR, iFR, cząstkowa rezerwa przepływu wieńcowego, rewaskularyzacja serca, przezskórna interwencja wieńcowa, DEFINE-FLAIR, iFR-SWEDEHEART

Folia Cardiologica 2018; 13, 3: 236-239

\section{Cząstkowa rezerwa przepływu}

Pomiar cząstkowej rezerwy przepływu wieńcowego (FFR, fractional flow reserve) jest precyzyjną oceną istotności zwężenia w naczyniach wieńcowych, którą można łatwo i szybko wykonać w trakcie koronarografii. Przyjęto, że wartość FFR nie wyższa niż 0,80 identyfikuje zwężenie naczynia powodujące niedokrwienie z dokładnością powyżej 90\% [1, 2]. Umożliwia to określenie, czy oceniane zwężenie jest istotne hemodynamicznie i wymaga rewaskularyzacji, czy wystarczy leczenie farmakologiczne.

Ocena FFR od lat stanowi podstawowe narzędzie w kardiologii interwencyjnej przy podejmowaniu decyzji dotyczącej stentowania zmienionego naczynia. Graniczne wizualnie zwężenia podczas koronarografii w pomiarze FFR niejednokrotnie okazują się nieistotne hemodynamicznie, co umożliwia odstąpienie od przezskórnej interwencji wieńcowej (PCl, percutaneous coronary intervention). Diagnostyka przy użyciu FFR polega na pomiarze ciśnienia za zwężeniem i przed nim przy użyciu prowadnika ciśnieniowego, wyliczony ich stosunek informuje o istotności zwężenia. Wartość wynosząca 0,80 lub mniej świadczy o hemodynamicznie istotnej zmianie miażdżycowej w naczyniu wieńcowym wymagającym rewaskularyzacji. Pacjenci z FFR powyżej 0,80 kwalifikują się do leczenia zachowawczego, a odraczanie $\mathrm{PCl}$ lub pomostowania tętnic wieńcowych;

Adres do korespondencji: lek. Bartosz Górny, Il Katedra Kardiologii, Uniwersytet Mikołaja Kopernika w Toruniu, Collegium Medicum w Bydgoszczy, ul. Ujejskiego 75, 85-168 Bydgoszcz, tel. 5236556 53, e-mail: gornyb@wp.pl 
(CABG, coronary artery bypass grafting) u takich pacjentów wydaje się bezpieczne [3-5]. Analiza FFR jest cennym narzędziem diagnostycznym u pacjentów poddawanych koronarografii bez wcześniejszych nieinwazyjnych badań czynnościowych, zwłaszcza w przypadku obecności granicznych zmian, a także u osób z chorobą wielonaczyniową (MVD, multivessel disease). Odstępowanie od niepotrzebnej PCl zmian nieistotnych hemodynamicznie potwierdzono w badaniach DEFER i FAME (Fractional Flow Reserve versus Angiography for Multivessel Evaluation) [3, 6].

Pomiar cząstkowej rezerwy przepływu wieńcowego jest metodą wymagającą maksymalnego i stabilnego przekrwienia (hiperemii), które zwykle uzyskuje się przez dożylne podanie adenozyny, czyli substancji o silnym działaniu wazodylatacyjnym. Wiąże się to jednak z niepożądanymi działaniami odczuwanymi przez pacjenta oraz zwiększa koszt zabiegu. Dlatego w celu uproszczenia diagnostyki i ułatwienia większego upowszechnienia zaproponowano nowe metody i wskaźniki, w tym rozkurczową ocenę gradientu ciśnienia (iFR, instantaneous wave-free ratio), która nie opiera się na koncepcji hiperemii.

\section{iFR - alternatywa dla FFR}

Badanie iFR jest pomocniczym, alternatywnym narzędziem w ocenie istotności zwężenia naczynia wieńcowego, które umożliwia analizę tych zmian podczas rozkurczu. W odróżnieniu od FFR w metodzie tej nie ma konieczności stosowania leków indukujących hiperemię, na przykład adenozyny, dzięki czemu jest badaniem stosunkowo krótkim i lepiej tolerowanym przez pacjenta. Polega na pomiarze spoczynkowego gradientu ciśnień, jest ilorazem średniego ciśnienia mierzonego za zwężeniem w okresie rozkurczu (wave-free) i ciśnienia mierzonego w aorcie w trakcie tego samego okresu. Przyjęto, że uzyskanie wyniku iFR co najmniej 0,94 pozwala na odstąpienie od $\mathrm{PCl}$, w przypadku uzyskania wyniku równego 0,85 i niższego $\mathrm{PCl}$ jest wskazana, natomiast wartość iFR w zakresie 0,86-0,93 jest „szarą strefą” - należy wówczas wykonać badanie FFR (podejście hybrydowe iFR-FFR). Obie metody porównano w badaniu ADVISE 2 (ADenosine Vasodilator Independent Stenosis Evaluation II), w którym przeanalizowano 690 zwężeń wśród 598 pacjentów. Okazały się one zgodne. Ustalony próg odcięcia dla iFR wynoszący 0,89 był optymalny, dzięki czemu prawidłowo sklasyfikowano 82,5\% zwężeń, z kolei w połączeniu z FFR prawidłowo sklasyfikowano aż 94,2\% [7].

\section{iFR a FFR - wyniki badań iFR-SWEDEHEART i DEFINE-FLAIR}

Podczas zakończonej niedawno konferencji American College of Cardiology (ACC) w 2017 roku podczas Scientific Sessions w Waszyngtonie przedstawiono wyniki dwóch dużych, randomizowanych badań: iFR-SWEDEHEART
(Instantaneous Wave-free Ratio versus Fractional Flow Reserve in Patients with Stable Angina Pectoris or Acute Coronary Syndrome) i DEFINE-FLAIR (Functional Lesion Assessment of Intermediate Stenosis to Guide Revascularisation), w których bezpośrednio porównano iFR z FFR przy podejmowaniu decyzji o rewaskularyzacji u blisko 4500 pacjentów [8, 9]. Do obu badań włączono chorych ze stabilną dławicą piersiową lub ostrymi zespołami wieńcowymi bez uniesienia odcinka ST (NSTE ACS, non-ST elevation acute coronary syndrome), u których wykonano koronarografię i zakwalifikowano do oceny istotności zwężenia w naczyniu wieńcowym (głównie w naczyniach o umiarkowanej stenozie). Punkty odcięcia w przypadku obu metod wynosiły: dla iFR nie wyższe niż 0,89 oraz dla FFR równe 0,80 lub niższe - wówczas kwalifikowano pacjentów do rewaskularyzacji metodą PCl lub CABG, natomiast gdy uzyskane wartości były wyższe, odstępowano od interwencji.

Pierwsze badanie iFR-SWEDEHEART przeprowadzono głównie w kilkunastu ośrodkach w Szwecji, do którego włączono do grupy iFR lub FFR 2037 pacjentów ze zwężeniami wieńcowymi 40-80\% w ocenie wizualnej. Średnia wieku wyniosła 68 lat; $62 \%$ stanowiły osoby ze stabilną dławicą piersiową, a 33\% przebyło w przeszłości zawał serca. W grupie iFR oceniono więcej zwężeń (1568 v. 1436), 29,1\% z nich okazało się istotnych hemodynamicznie, z rewaskularyzacją u 536 pacjentów, natomiast w grupie FFR istotnych było $36,8 \%$ zmian, z rewaskularyzacją u 569 osób. Jednoroczne wyniki głównego punktu końcowego (zgon z jakiejkolwiek przyczyny, zawał serca niepowikłany zgonem oraz ponowna rewaskularyzacja) wyniosły $6,7 \%(68 / 1012)$ i $6,1 \%$ (61/1007), odpowiednio dla iFR oraz FFR ( $p=0,007$ dla non-inferiority). Wyniki drugorzędowych punktów końcowych były porównywalne w obu grupach (m.in. zgony z jakiekolwiek przyczyny 1,5\% [15 osób] v. 1,2\% [12 osób], w tym z przyczyn sercowych 8 v. 6 osób).

Drugie badanie DEFINE-FLAIR zawiera dane $z$ analiz przeprowadzonych wśród chorych z 49 ośrodków z Europy, Azji, Afryki, Bliskiego Wschodu, Stanów Zjednoczonych i Australii. Włączono do niego 2492 osób z chorobą wieńcową (CAD, coronary artery disease) z przynajmniej jednym zwężeniem, którego istotność była kwestionowana (w ocenie wizualnej 40-70\%). Wśród badanych $80 \%$ stanowiły osoby ze stabilną dławicą piersiową, a średni wiek wyniósł 65 lat. Liczba ocenionych naczyń wieńcowych nie różniła się istotnie: 1575 versus 1608 (odpowiednio dla iFR i FFR, $p=0,58$ ). Pierwszorzędowy punkt końcowy (definiowany jak w badaniu iFR-SWEDEHEART) wystąpił u 6,8\% chorych z grupy iFR (78/1148) i 7,0\% z grupy FFR (83/1182) ( $p<0,001$ dla non-inferiority). Warto zauważyć, że więcej zgonów z jakiejkolwiek przyczyny odnotowano w grupie iFR niż FFR: 1,9\% w porównaniu z 1,1\% ( $p=0,11)$, oraz z przyczyn sercowo-naczyniowych, odpowiednio: 0,6\% w porównaniu z 0,3\%. Doktor J. Davies (Imperial College w Londynie), jeden ze współautorów badania, w wywiadzie podczas 
ACC w 2017 roku podkreślił, że były to zgony z wszystkich przyczyn, a większość z nich miała przyczyny pozasercowo-naczyniowe - były to w szczególności nowotwory) [10].

Przeprowadzenie FFR wymaga użycia adenozyny do oceny istotności zwężenia w naczyniu wieńcowym, co wiąże się z większym dyskomfortem pacjentów, poza tym jest metodą droższą i dłużej trwającą. Głównymi działaniami niepożądanymi związanymi z adenozyną było uczucie duszności, bólu w klatce piersiowej lub odnotowane zaburzenia rytmu serca. W badaniu iFR-SWEDEHEART w grupie iFR rzadziej występował ból w klatce piersiowej w trakcie oceny zwężenia niż podczas wykonywania FFR (3,0\% v. 68,3\%, $p<0,001)$, z kolei w DEFINE-FLAIR zgłaszane niepożądane działania w postaci duszności i bólu w klatce piersiowej wystąpiły u 3,1\% chorych z grupy iFR w porównaniu z 30,8\% $w$ grupie FFR ( $p<0,001)$. Średni czas trwania iFR wyniósł 40,5 min w badaniu DEFINE-FLAIR oraz 50,8 min w iFR-SWEDEHEART, natomiast średni czas FFR - odpowiednio: $45 \min$ i $53,1 \min [8,9]$.

\section{Podsumowanie}

Mimo wyników wielu randomizowanych badań i dostępnych silnych dowodów nadal niezbyt często wykonuje się oceny FFR. Być może jedną z przyczyn jest konieczność użycia adenozyny w trakcie analizy i związane z tym działania niepożądane oraz wydłużony czas badania. Stosunkowo nowa metoda, jaką jest iFR, może się okazać przydatną alternatywą; jest badaniem prostszym, tańszym i przede wszystkim lepiej tolerowanym przez pacjentów. Wyniki przytoczonych badań wskazują, że iFR okazała się metodą równie skuteczną jak FFR, z porównywalnym głównym punktem końcowym w ocenie rocznej głównych niekorzystnych zdarzeń sercowo-naczyniowych (MACE, major adverse cardiac events). Rezultaty te sugeruja, że korzyści rewaskularyzacji naczyń wieńcowych z oceną FFR mogą być osiągnięte także przy użyciu iFR. Ponadto iFR może być przydatna w ocenie rozsianych zwężeń, tandemowych, taka analiza wymaga jednak dalszych dodatkowych badań [11].

Obecnie stosunkowo rzadko wykorzystuje się iFR, spora grupa kardiologów interwencyjnych przyzwyczaiła się już do FFR, część nadal pozostaje sceptyczna wobec wykorzystywania metod oceny fizjologii zwężenia, ponadto iFR jest narzędziem stosowanym tylko przez jednego producenta. Jednak opublikowane wyniki badań DEFINE-FLAIR oraz iFR-SWEDEHEART wskazują, że warto wziąć pod uwagę alternatywną metodę iFR, która okazała się równie skuteczna jak FFR. Pozostaje czekać na kolejne wyniki badań, w których te metody zostaną porównane, oraz dalszą odległą obserwację chorych poddanych analizie istotności zwężeń w naczyniach wieńcowych.

\section{Konflikt interesów}

Autorzy deklarują brak konfliktu interesów.

\section{Abstract}

Fractional flow reserve (FFR) is a technique, which allows the accurate assessment of stenosis severity and can be easily and quickly measured during coronary angiography. For past years, FFR has been a basic tool in interventional cardiology, allowing to assess the potential benefit of revascularisation of coronary artery disease. Instantaneous wave-free ratio (iFR) is a recently developed, helpful physiological index, used to evaluate the severity of stenosis, calculated by measuring the resting pressure gradient across a coronary lesion during the portion of diastole. During the American College of Cardiology 2017 Scientific Session in Washington, the outcomes of two large, randomised trials were presented: iFR-SWEDEHEART and DEFINE-FLAIR, comparing iFR vs FFR with a combined total of 4,500 patients. The outcomes show, that iFR is non-inferior to FFR, with similar rates of major adverse cardiac events. We have to wait for the results from further randomised studies, comparing FFR with iFR and long-term follow-up of patients, who were assigned to undergo evaluation of stenosis severity.

Key words: FFR, iFR, fractional flow reserve, instant wave-free ratio, revascularisation, percutaneous coronary intervention, DEFINE-FLAIR, iFR-SWEDEHEART

Folia Cardiologica 2018; 13, 3: 236-239

\section{Piśmiennictwo}

1. Pijls NH, Van Gelder B, Van der Voort P, et al. Fractional flow reserve. A useful index to evaluate the influence of an epicardial coronary stenosis on myocardial blood flow. Circulation. 1995; 92(11): 3183-3193, indexed in Pubmed: 7586302.
2. Pijls NH, De Bruyne B, Peels K, et al. Measurement of fractional flow reserve to assess the functional severity of coronary-artery stenoses. N Engl J Med. 1996; 334(26): 1703-1708, doi: 10.1056/ /NEJM199606273342604, indexed in Pubmed: 8637515. 
3. Pijls NHJ, van Schaardenburgh P, Manoharan G, et al. Percutaneous coronary intervention of functionally nonsignificant stenosis: 5-year follow-up of the DEFER Study. J Am Coll Cardiol. 2007; 49(21): 2105-2111, doi: 10.1016/j.jacc.2007.01.087, indexed in Pubmed: 17531660.

4. Botman KJ, Pijls NHJ, Bech JW, et al. Percutaneous coronary intervention or bypass surgery in multivessel disease? A tailored approach based on coronary pressure measurement. Catheter Cardiovasc Interv. 2004; 63(2): 184-191, doi: 10.1002/ccd.20175, indexed in Pubmed: 15390344.

5. Toth G, De Bruyne B, Casselman F, et al. Fractional flow reserve-guided versus angiography-guided coronary artery bypass graft surgery. Circulation. 2013; 128(13): 1405-1411, doi: 10.1161/CIRCULATIONAHA.113.002740, indexed in Pubmed: 23985788.

6. Tonino PAL, Fearon WF, De Bruyne B, et al. Angiographic versus functional severity of coronary artery stenoses in the FAME study fractional flow reserve versus angiography in multivessel evaluation. J Am Coll Cardiol. 2010; 55(25): 2816-2821, doi: 10.1016/j. jacc.2009.11.096, indexed in Pubmed: 20579537.
7. Escaned J, Echavarría-Pinto M, Garcia-Garcia HM, et al. ADVISE II Study Group. Prospective assessment of the dagnostic accuracy of instantaneous wave-free ratio to assess coronary stenosis relevance: results of ADVISE II international, multicenter study (ADenosine Vasodilator Independent Stenosis Evaluation II). JACC Cardiovasc Interv. 2015; 8(6): 824-833, doi: 10.1016/j.jcin.2015.01.029, indexed in Pubmed: 25999106.

8. Davies JE, Sen S, Dehbi HM, et al. Use of the instantaneous wave-free ratio or fractional flow reserve in PCl. N Engl J Med. 2017; 376(19): 1824-1834, doi: 10.1056/NEJMoa1700445, indexed in Pubmed: 28317458.

9. Götberg M, Christiansen EH, Gudmundsdottir IJ, et al. iFR-SWEDEHEART Investigators. Instantaneous wave-free ratio versus fractional flow reserve to guide PCl. N Engl J Med. 2017; 376(19): 1813-1823, doi: 10.1056/NEJMoa1616540, indexed in Pubmed: 28317438.

10. https://www.tctmd.com/news/ifr-matches-ffr-clinical-outcomes-patients-intermediate-lesions (06.07.2017).

11. Bhatt DL. Assessment of stable coronary lesions. N Engl J Med. 2017; 376(19): 1879-1881, doi: 10.1056/NEJMe1702728, indexed in Pubmed: 28317425. 